\title{
Bottom-up and top-down control of heterotrophic bacterioplankton growth in a phosphorus-depleted subtropical estuary, Florida Bay, USA
}

\author{
Clayton J. Williams ${ }^{1}$, Peter J. Lavrentyev ${ }^{2}$, Frank J. Jochem ${ }^{1, *}$ \\ ${ }^{1}$ Marine Biology Program, Florida International University, 3000 N.E. 151st Street, North Miami, Florida 33134, USA \\ ${ }^{2}$ Department of Biology, University of Akron, 181 ASEC-W, Akron, Ohio 44325, USA
}

\begin{abstract}
The influences of resources (carbon, nitrogen, and phosphorus) and protist bacterivory on heterotrophic bacterioplankton growth rates were investigated at 4 sampling sites in the subtropical Florida Bay seagrass estuary during 3 seasons, summer 2004, winter 2005, and fall 2006. Bacterial growth and grazing mortality rates were determined by dilution experiments and flow cytometry, where bacterial communities were separated into high and low DNA content populations (HDNA and LDNA, respectively). In addition, methylumbelliferyl-heptanoate hydrolysis assays were used to measure ambient esterase activity and to determine the impact of resources and grazing on esterase activity. Total bacterial gross growth, grazing mortality, and net growth rates ranged from 0.41 to $1.72,0.32$ to 1.46 , and -0.17 to $0.41 \mathrm{~d}^{-1}$, respectively. HDNA bacteria gross growth and grazing mortality rates were consistently higher than LDNA gross growth and grazing mortality rates. However, LDNA bacteria were not inactive and exhibited positive gross and net growth rates. Stepwise linear multiple regression analysis indicated that $\ln$-transformed ammonium concentration and ambient esterase activity related significantly and positively to total bacteria net growth rates $\left(R^{2}=0.75\right)$. When total bacterial mortality rates met or exceeded gross growth rates (i.e. negative or zero net growth rates), esterase activity increased with the reduction of grazing pressure without nutrient addition. When bacterial gross growth rates exceeded bacterial grazing mortality rates (i.e. positive net growth rates), both reduction of grazing pressure and nutrient amendments were required to stimulate esterase activity. These results suggest that bottom-up processes regulated heterotrophic bacterial growth, abundance, and carbon use when ammonium concentrations were high and phosphate concentrations were low (i.e. high inorganic N:P ratios). Under low ammonium concentrations and relatively increased phosphate concentrations (i.e. low N:P ratios), top-down processes regulated heterotrophic bacterioplankton growth, abundance, and carbon use in Florida Bay, USA.
\end{abstract}

KEY WORDS: Microbial food web · Esterase activity $\cdot$ Lipase activity $\cdot$ Grazing $\cdot$ Bacteria $\cdot$ Flow cytometry

\section{INTRODUCTION}

Heterotrophic bacterioplankton are important decomposers of organic matter and recyclers of inorganic nutrients in marine environments. Bacterioplankton are prey to nano- and microzooplankton-sized grazers, where protists, especially heterotrophic nanoflagellates (HNF), constitute the primary bacterivores and conduits of bacterial production (BP) to higher trophic levels (Sherr \& Sherr 2002). Bacterial growth can be regulated by bottom-up (resource-limited) or topdown (grazer-restricted) processes. In ecosystems with low inorganic nutrient concentrations, the limiting nutrient(s), in theory, can set the level of bacterial growth and abundance, which then regulates the biomass of bacterivores (Sanders et al. 1992). Resource status or trophic level of an aquatic ecosystem might, however, not be the best predictor of bottom-up or top- 
down control of bacterial growth (Gasol et al. 2002). Protists can respond to changes in environmental cues such as the growth, metabolic activity, size, density, and community structure of their prey by altering activity, feeding strategies, and for mixotrophic species their mode of nutrition (Gasol et al. 1999, Jürgens \& Matz 2002, Sherr \& Sherr 2002).

In Florida Bay, USA, and other seagrass-dominated estuaries, bacterioplankton play an important role in transferring primary production to higher food webs. In unimpacted seagrass estuaries, phytoplankton biomass and water column inorganic nutrient concentrations are generally low, but the water column is enriched in organic matter due to high rates of benthic primary productivity (Boyer et al. 1999, Ziegler \& Benner 1999). In these ecosystems, bacterioplankton have access to a wide variety of carbon sources, which can uncouple bacterial reliance on phytoplankton as their sole carbon source. Such uncoupling allows bacteria to compete successfully with phytoplankton for limiting nutrients (Cotner et al. 2000). In these net heterotrophic pelagic environments, bacterioplankton might experience stronger than expected top-down control due to their importance as a link between benthic production and pelagic carbon cycling.

Much of water column organic matter is not directly accessible by heterotrophic bacteria, which must induce extracellular enzymes (enzymes attached to microbial cell walls or freely dissolved) to use high molecular weight (>600 Da) organic matter. Esterase/ lipases are an important class of enzymes produced by all microorganisms and are used to hydrolyze a wide variety of ester bonds of biologically important compounds (Bornscheuer 2002). Esterase/lipase activities in aquatic communities have been used to determine bacterial carbon use (Taylor et al. 2003, Williams \& Jochem 2006), bacterial metabolic activity (Gilham \& Lehner 2005), bacterial functional diversity (Knopoka \& Zakharova 2002), and phytoplankton cell lysis (Agustí et al. 1998). In Florida Bay, esterase activity was significantly higher than the more commonly measured alkaline phosphatase and aminopeptidase activities and was not a direct consequence of substrate availability or phytoplankton biomass (Williams \& Jochem 2006). The purpose of esterase activity in this estuary is currently not well understood. One hypothesis is that esterase activity in Florida Bay is linked to bacterial community growth, in which esterases are used to supply carbon for bacterial catabolism. In cultured bacteria, esterase/lipase activity peaked during exponential growth but was reduced during the stationary phase (Jaeger et al. 1994, Gobbetti et al. 1997).

The primary goal of the present study was to determine bottom-up and top-down influences on heterotrophic bacterioplankton growth in Florida Bay. The secondary goal was to investigate controls on extracellular esterase enzyme activity in Florida Bay. Modified serial dilution experiments (Landry \& Hassett 1982, Landry et al. 1995, Caron 2001) were used to determine bacterial growth and grazing mortality rates in Florida Bay, whereby bacterial populations were distinguished as high and low DNA content bacteria (HDNA and LDNA, respectively) by flow cytometry (Jochem et al. 2004). In addition, esterase activity assays were conducted under different grazer abundance (dilution) and nutrient (ambient and enriched) treatments. This experimental design allowed simultaneous determination of esterase activity, bacterial growth, and bacterial grazing mortality.

\section{MATERIALS AND METHODS}

Study site and sampling procedures. Florida Bay is a shallow $(<2 \mathrm{~m})$ subtropical seagrass estuary located at the southern tip of the Florida peninsula. Florida Bay is open to the Gulf of Mexico in the west and separated from the Atlantic Ocean in the south and east by the semi-permeable barrier of the Florida Keys (Fig. 1). Four stations (Duck Key, northeast bay [NE]; Little Rabbit Key, south-central bay [SC]; Rankin Key, northcentral bay $[\mathrm{NC}]$; and Murray Key, northwest bay [NW]) were sampled during summer 2004 (August 18 to 26), winter 2005 (January 7 to 15), and fall 2006 (November 10 to 18). These stations were used in previous studies on microbial food webs (Lavrentyev et al.

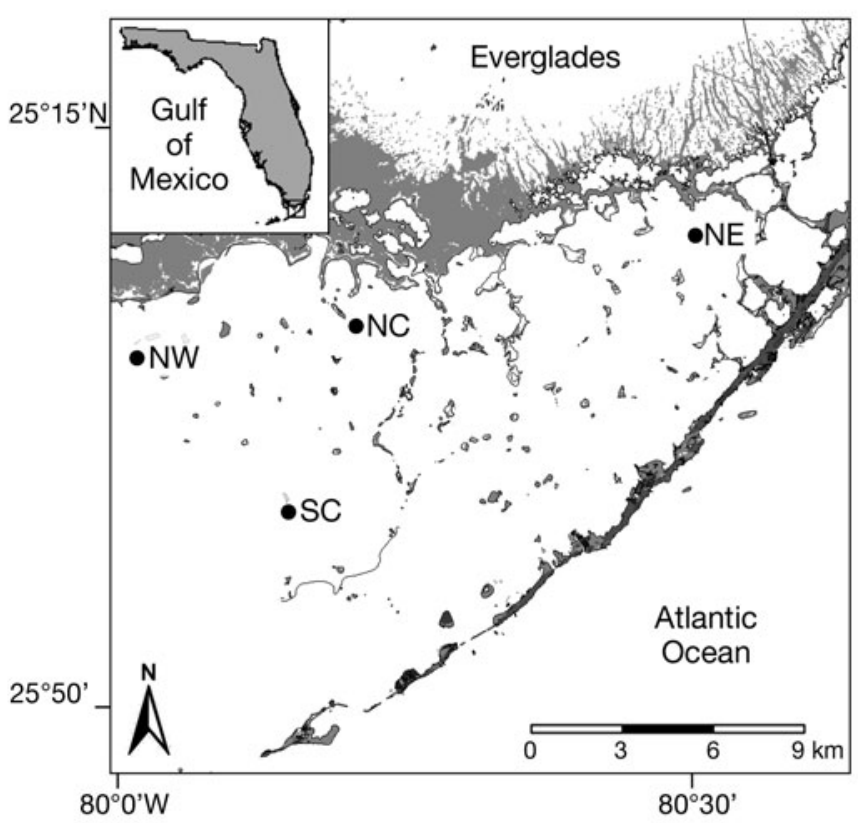

Fig. 1. Florida Bay area. Sampling stations: northeast (NE), south-central (SC), north-central (NC), and northwest (NW) 
1998) and phosphorus (Cotner et al. 2000) and nitrogen cycling (W. S. Gardner unpubl. data), and are part of the continuous water quality monitoring program in Florida Bay. Based on previous studies (Fourqurean et al. 1993, Lavrentyev et al. 1998, Cotner et al. 2000, Williams \& Jochem 2006) and data from the Florida Bay water monitoring program (Boyer et al. 1999), NE was expected to be phosphorus-limited (bottom-up controlled) and have the least top-down influence from bacterivorous protists. NC was expected to have a more balanced inorganic nutrient stoichiometry (i.e. close to 16:1 Redfield ratios) and the highest protist biomass. SC and NW were expected to act as transition stations between the nitrogen-limited Gulf of Mexico and the phosphorus-limited eastern Florida Bay, where bottom-up and top-down forces co-influence heterotrophic bacterioplankton communities. Dilution experiments and esterase assays were not conducted at SC during fall 2006.

Once per season at each station, ca. 401 surface water were collected in acid-washed, sample-rinsed polycarbonate bottles. Inorganic nutrient samples were filtered ( $0.2 \mu \mathrm{m}$ pore size) at the time of collection and frozen for later analysis. Water for dilution experiments and esterase analyses was stored shaded on the boat deck until laboratory processing, usually within 2 to $4 \mathrm{~h}$ of collection.

Environmental variables. Temperature and salinity were measured with a Hydrolab DataSonde/Surveyor 4. $\mathrm{NO}_{2}{ }^{-}+\mathrm{NO}_{3}{ }^{-}$and $\mathrm{PO}_{4}{ }^{3-}$ concentrations were determined on a Lachat QuikChem 8000 flow injection analyzer. $\mathrm{NH}_{4}{ }^{+}$concentrations were determined by high performance liquid chromatography (HPLC) (Gardner et al. 1995).

Chlorophyll a ( $\mathrm{chl} \mathrm{a)} \mathrm{concentration} \mathrm{was} \mathrm{determined}$ from particles collected on $0.2 \mu \mathrm{m}$ pore-size $47 \mathrm{~mm}$ NylaFlo membrane filters from 0.05 to 11 water samples. Chl a was extracted in $90 \%$ acetone for $24 \mathrm{~h}$ at $-20^{\circ} \mathrm{C}$ and measured on a Turner TD-700 fluorometer calibrated with internal commercial standards. In fall 2006, particles collected on membrane filters were manually ground and then extracted for chl a.

Total bacterial abundance (TBAC) was determined on a FACSort flow cytometer after treating with RNAse and staining with SYBR Green I in the presence of $30 \mathrm{mmol} \mathrm{l}^{-1}$ potassium citrate (Marie et al. 1997, Jochem 2001). Bacteria were separated into HDNA and LDNA subpopulations based on side-angle light scatter (SSC) and green fluorescence (FL1, $535 \pm$ $15 \mathrm{~nm}$ ) relative intensities (Jochem et al. 2004).

Between 5 and $15 \mathrm{ml}$ of formaldehyde-preserved ( $2 \%$ final concentration) samples were concentrated onto $0.45 \mu \mathrm{m}$ pore-size $25 \mathrm{~mm}$ black polycarbonate membrane filters, stained with DAPI, and counted under a fluorescent microscope using a dual-band (UV and green excitation) filter set. Random fields were scanned until at least 200 cells were counted. HNF were distinguished from autotrophic nanoplankton by the absence of chlorophyll autofluorescence. Ciliates and dinoflagellates (plastidic and aplastidic) were preserved with acid Lugol's iodine (5\% final concentration) and counted and measured in 50 to $100 \mathrm{ml}$ Utermöhl settling chambers using differential interference contrast microscopy. The entire chamber was scanned to quantify microzooplankton. Length and width (taken as the longest dimensions) of at least 40 cells per abundant protist group (i.e. HNF, aloricate ciliates, tintinnids, thecate and athecate dinoflagellates, etc) were measured using an eyepiece micrometer at 400 to $600 \times$ and $1000 \times$ magnifications for microzooplankton and HNF, respectively. Cell volumes of protists were calculated from their linear dimensions by applying the approximate geometric shape and converted to carbon according to Putt \& Stoecker (1989) and Menden-Deuer \& Lessard (2000).

Dilution experiments. A modified dilution experiment approach was used to determine TBAC, HDNA, and LDNA bacterial gross growth, grazing mortality, and net growth rates (our Fig. 2; Landry \& Hassett 1982, Landry et al. 1995, Caron 2001). Sample water was pre-screened through a $153 \mu \mathrm{m}$ mesh to remove large zooplankton. One hundred, 80, 60, 30, and 10\% of whole water serial dilutions were prepared with $0.2 \mu \mathrm{m}$ pore-size, $1350 \mathrm{~cm}^{2}$ surface area Versapor (Pall) cartridge gravity-filtered ambient water. The use of large-area filter cartridges and gravity flow is expected to have avoided organic carbon enrichment by cell damage during filtration. This assumption was confirmed in a later, independent experiment measuring effects of the employed filtration technique by direct measurements of dissolved organic carbon (DOC) (Shimadzu TOC-5000) in unfiltered and filtered water, which did not show a significant change in DOC concentration upon filtration (authors' unpubl. data). Nitrogen and phosphorus ( $\mathrm{N}+\mathrm{P}_{i} \mathrm{NH}_{4} \mathrm{NO}_{3}+\mathrm{K}_{2} \mathrm{HPO}_{4}$ ) were added to the dilution series at $1.59 \mu \mathrm{mol} \mathrm{N}{ }^{-1}$ and $0.79 \mu \mathrm{mol} \mathrm{P} \mathrm{l}^{-1}$ final concentration, which was 0.4 to 7 times and 10 to 100 times ambient $\mathrm{N}$ and $\mathrm{P}$ concentrations, respectively (see Table 1). Nutrient addition relieved potential nutrient limitation of bacteria and was necessary to avoid underestimating bacterial grazing morality rates (Landry \& Hassett 1982). In addition, 100 and $10 \%$ of whole water control (no nutrient amendments) and $<25 \mu \mathrm{m}$ plus $\mathrm{N}+\mathrm{P}$ (summer 2004, winter 2005, and at NW in fall 2006) treatments were prepared. Finally, in fall 2006, carbon only and carbon plus $\mathrm{N}+\mathrm{P}$ treatments were added to the dilution experiments to test for carbon limitation of bacterial growth rates. Carbon treatments received $390 \mu \mathrm{mol}$ $\mathrm{C}^{-1}$ final concentration in equal parts of acetate, pyru- 


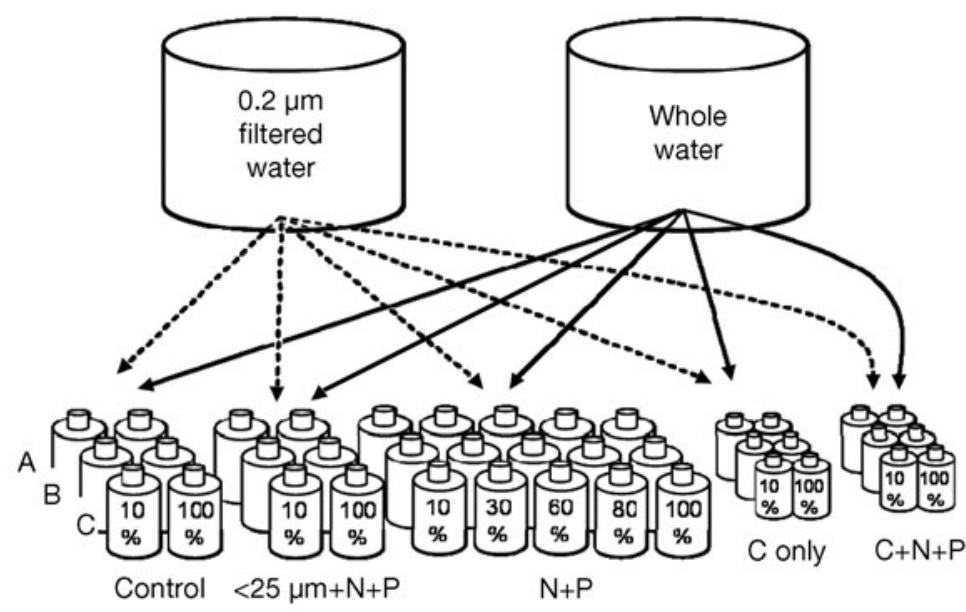

Fig. 2. Dilution experiment diagram. Whole water and $0.2 \mu \mathrm{m}$ cartage-filtered water were mixed together to produce 10, 30, 60, 80, and $100 \%$ whole water dilution series and nutrient treatments. Each treatment was incubated in triplicate (i.e. A, B, C) using 500 or $250 \mathrm{ml}$ clear polycarbonate incubation bottles. Bacterial abundance samples were collected initially $\left(T_{0}\right)$ and at the end of incubation $\left(T_{24}\right)$ from each bottle $(\mathrm{n}=3) . T_{0}$ and $T_{24}$ esterase activities were only determined in 10 and $100 \%$ whole water dilutions. Esterase activities for control treatments were replicated as just described, but amended treatments were pooled $(A+B+C)$ for analysis and error reported for between-nutrient amendment treatments ( $\mathrm{n}=2$ or 3 depending on season). Size fraction $<25 \mu \mathrm{m}$ with nitrogen and phosphorus amendments treatment was used in summer 2004, winter 2005, and at the northwest station in fall 2006. Carbon only and carbon + nitrogen + phosphorus treatments were only used in fall 2006

vate, glucose, and fructose, constituting a 35 and $23 \%$ increase in carbon from the long-term median total organic carbon concentration in eastern and central regions, respectively, of Florida Bay (Boyer et al. 1999).

All dilutions and treatments were incubated in triplicate using $500 \mathrm{ml}$ (control, $<25 \mu \mathrm{m}$ plus $\mathrm{N}+\mathrm{P}$, and $\mathrm{N}+\mathrm{P})$ or $250 \mathrm{ml}(\mathrm{C}$ only and $\mathrm{C}+\mathrm{N}+\mathrm{P})$ clear polycarbonate bottles (Fig. 2). All bottles were incubated under in situ light levels, photoperiod, and temperature for $24 \mathrm{~h}$. At initial $\left(T_{0}\right)$ and final $\left(T_{24}\right)$ incubation times, water was collected for bacterial abundance and esterase activity determination.

Total, HDNA, and LDNA bacterial grazing mortality rates were estimated as the negative slope of the linear regression line of the $\mathrm{N}+\mathrm{P}$ dilution series and apparent growth rate at each dilution (Caron 2001). One criticism of the original Landry \& Hassett (1982) serial dilution experiment was that nutrient addition can stimulate microbial growth, causing overestimation of net bacterial growth rates (Landry et al. 1995, First et al. 2007). To account for this concern, net bacterial growth rates (TBAC, HDNA, and LDNA) were estimated from $100 \%$ control treatments as $\ln \left(N_{T_{0}} / N_{T_{24}}\right)$, where $N$ is the group specific bacterial abundance at $T_{0}$ and $T_{24}$ (Caron 2001). Bacterial gross growth rates were calculated as the sum of grazing rates and control treatment net growth rates.
Esterase activity assays. Methylumbelliferyl(MUF)-heptanoate was used to measure extracellular esterase activity (Williams \& Jochem 2006). MUF-heptanoate is a fluorogenic model substrate analog for esterlinked organic acids with a chain length of 7 carbons (C7). By definition, esterases hydrolyze the ester bond of short chain $(\leq \mathrm{C} 10)$ mono-, di-, and triacylglycerol and a variety of esters of short-chain organic acids. In nature, esterase/lipase enzymes have broad substrate specificity and the chemical characteristics of the enzymes that are capable of hydrolyzing MUF-heptanoate are not known (Bornscheuer 2002, Gilham \& Lehner 2005). Therefore, esterase activities reported here likely included activity from lipases, which have greater specificity, for long-chain $(\geq \mathrm{C} 10)$ organic acids and triacylglycerides.

Esterase activities (i.e. maximum hydrolysis rate, $V_{\max }$ ) for the medium chain length MUF-heptanoate were determined by the Michaelis-Menten kinetic model. Activities were based on changes in fluorescence over $3 \mathrm{~h}$ incubations at 4 model substrate concentrations $\left(10,25,100\right.$, and $\left.200 \mu \mathrm{mol} \mathrm{l}^{-1}\right)$. Fluorescence was measured on a BioTek FLx800TB computer-controlled plate reader and fluorescent units converted to substrate concentration using MUF standard curves. Ambient esterase activity is reported as $\mu \mathrm{mol} \mathrm{l}^{-1} \mathrm{~h}^{-1}$.

Esterase activities were measured in 100 and $10 \%$ dilution treatments at $T_{0}$ and $T_{24}$, where $T_{0} \quad 100 \%$ control was deemed the ambient esterase activity. Given the large number of incubation wells needed to determine esterase enzyme activities for triplicate bottle incubations (288 per station), it was not possible to measure each treatment and dilution in triplicate at $T_{24}$. Instead, the triplicate incubations at each dilution for each treatment, excluding control incubations, were pooled. The pooled samples were replicated for MUF fluorescence measurement accuracy. To allow statistical comparison with esterase activities in 100 and $10 \%$ control dilutions, nutrientamended treatments (i.e. $<25 \mu \mathrm{m}$ plus $\mathrm{N}+\mathrm{P}, \mathrm{N}+\mathrm{P}, \mathrm{C}$ only, and $\mathrm{C}+\mathrm{N}+\mathrm{P}$ ) were averaged at $T_{24}$. Thereby, the impact of dilution and general nutrient amendment on esterase activity was investigated. In order to simplify these results and allow comparison between stations and years, esterase activities from the dilution experiment are reported as $\Delta$ esterase, which is the difference in esterase activity between $T_{24}$ and $T_{0}$ as $\mu \mathrm{mol} \mathrm{l}^{-1}$ or normalized to $T_{0}$ esterase activity and expressed as \%. 
Explicitly separating 100 and $10 \%$ treatments allowed the impact of grazing on esterase activity to be determined. One assumption of the dilution experiment is that prey growth rates are not changed by the dilution and the predator-prey encounter rate is inversely proportional to sample dilution. Thus, 100\% whole water treatments received $100 \%$ grazing pressure and $10 \%$ of whole water treatments received $10 \%$ of full grazing pressure, because $90 \%$ of the grazers had been diluted out of the incubation. In this way, by comparing $\Delta$ esterase for control versus nutrientamended and 10 versus $100 \%$ dilution (i.e. the difference in $\Delta$ esterase), the grazing and nutrient amendment impact on esterase activity could be explored.

Statistical analysis. Environmental variables and ambient esterase activities were ln-transformed to meet the assumptions of equal variance and normality. Significant differences $(\alpha=0.05)$ for environmental conditions were resolved by ANOVA, considering the main effects (Season and Station) in the model. A full-model (Season, Station, and Season $\times$ Station) ANOVA was used to determine significant differences in TBAC, HDNA, and LDNA bacterial net growth, gross growth, and grazing mortality rates. The Games-Howell post hoc test was used to establish which pairs differed significantly. Ambient nutrient and grazing (i.e. dilution) impacts on $\Delta$ esterase were determined by paired $t$-tests $(\alpha=0.05)$. Correlation analysis was used to examine relationships between environmental parameters, ambient esterase activity, and dilution experiment results. Linear model II regression and stepwise multiple regression analyses were used to examine environmental controls on TBAC net growth rate and the difference in $\Delta$ esterase.

Table 1. Ambient environmental conditions at Florida Bay sampling stations

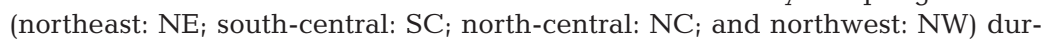
ing 3 seasons. DIN: dissolved inorganic nitrogen. nd: not detected; bld: below detection limits $\left(<0.1 \mu \mathrm{mol} \mathrm{l}^{-1}\right)$

\begin{tabular}{|lcccccc|}
\hline $\begin{array}{l}\text { Season } \\
\text { Stn }\end{array}$ & $\begin{array}{r}\text { Temp. } \\
\left({ }^{\circ} \mathrm{C}\right)\end{array}$ & Salinity & $\begin{array}{c}\mathrm{NO}_{2}{ }^{-}+\mathrm{NO}_{3}{ }^{-} \\
\left(\mu \mathrm{mol} \mathrm{l}^{-1}\right)\end{array}$ & $\begin{array}{c}\mathrm{NH}_{4}{ }^{+} \\
\left(\mu \mathrm{mol} \mathrm{l}^{-1}\right)\end{array}$ & $\begin{array}{c}\mathrm{PO}_{4}{ }^{3-} \\
\left(\mu \mathrm{mol} \mathrm{l}^{-1}\right)\end{array}$ & $\mathrm{DIN}: \mathrm{PO}_{4}{ }^{3-}$ \\
\hline Summer 2004 & & & & & & \\
NE & 30.9 & 41.4 & 1.8 & 1.8 & 0.11 & 27.9 \\
SC & 31.5 & 38.4 & 1.5 & 0.5 & 0.11 & 19.0 \\
NC & 31.8 & 37.9 & 1.7 & 1.5 & 0.06 & 53.1 \\
NW & 31.8 & 37.3 & 1.6 & bdl & 0.09 & 18.9 \\
Winter 2005 & & & & & & \\
NE & 22.9 & 41.3 & 2.3 & 4.5 & 0.04 & 170.5 \\
SC & 23.0 & 38.4 & 1.8 & 0.6 & 0.04 & 47.0 \\
NC & 23.2 & 45.0 & 1.5 & 0.4 & 0.02 & 96.0 \\
NW & 23.4 & 33.7 & 0.9 & 0.4 & 0.05 & 28.1 \\
Fall 2006 & & & & & & \\
NE & 24.9 & 31.4 & 0.8 & 0.4 & 0.05 & 24.1 \\
SC & 25.8 & 36.9 & 0.9 & nd & 0.17 & 5.2 \\
NC & 25.3 & 31.7 & 0.7 & nd & 0.12 & 6.2 \\
NW & 25.2 & 35.7 & 1.0 & nd & 0.06 & 17.3 \\
\end{tabular}

\section{RESULTS}

\section{Environmental variables}

Temperature ranged from 22.9 to $31.8^{\circ} \mathrm{C}$ and followed a seasonal pattern: summer $2004>$ fall $2006>$ winter 2005 ( $\mathrm{p}<0.001$; Table 1). Salinity ranged from 31.4 to 45.0 , did not differ between stations, and was significantly lower in fall $2006(\mathrm{p}=0.035) . \mathrm{NO}_{2}{ }^{-}+\mathrm{NO}_{3}{ }^{-}$ ranged from 0.7 to $2.3 \mu \mathrm{mol} \mathrm{l}^{-1}$ and were significantly lower in fall 2006 ( $\mathrm{p}=0.027) . \mathrm{NH}_{4}{ }^{+}$ranged from $<0.1$ (HPLC detection limit) to $4.5 \mu \mathrm{mol} \mathrm{l^{-1 }}$. $\mathrm{NH}_{4}{ }^{+}$was significantly lower in fall 2006 ( $\mathrm{p}=0.03$ ) and transitioned toward lower concentrations in the western bay ( $\mathrm{p}=$ 0.048). $\mathrm{PO}_{4}{ }^{3-}$ ranged from 0.02 to $0.17 \mu \mathrm{mol} \mathrm{l}^{-1}$ and was lowest in winter $2005(\mathrm{p}=0.025)$. Dissolved inorganic $\mathrm{N}$ (DIN): $\mathrm{PO}_{4}{ }^{3+}$ ratios (hereafter $\mathrm{N}$ :P ratios) ranged from 5.2 to 170.5 . In fall 2006, N:P ratios were significantly lower than in winter 2005 ( $\mathrm{p}=0.016)$, though summer 2004 ratios did not differ from those in the other seasons (Table 1).

Chl a ranged from 0.1 to $2.0 \mu \mathrm{g} \mathrm{l}^{-1}$ in summer 2004 and winter 2005. In fall 2006, chl a was significantly higher due to pronounced phytoplankton blooms

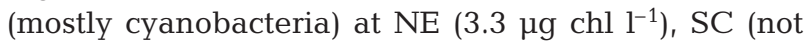

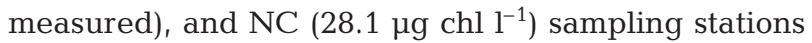
(Table 2). Total, HDNA, and LDNA bacterial abundance ranged from $0.6 \times 10^{9}$ to $15.2 \times 10^{9}, 0.3 \times 10^{9}$ to $12.9 \times 10^{9}$, and $0.2 \times 10^{9}$ to $2.3 \times 10^{9}$ cells $^{-1}$, respectively. The HDNA bacteria fraction was 51.8 to $85.1 \%$ of TBAC. TBAC was not significantly different between stations and seasons. TBAC peaked at NC during the fall 2006 phytoplankton bloom, due to a ca. 10-fold increase in both LDNA and HDNA bacteria. Ciliate and dinoflagellate biomass were variable and ranged from 2.1 to 14.5 and 1.6 to $54.0 \mu \mathrm{g} \mathrm{C} \mathrm{l}^{-1}$, respectively. HNF biomass ranged from 1.2 to $26.6 \mu \mathrm{g} \mathrm{C} \mathrm{l^{-1 }}$ and peaked in fall 2006 (Table 2).

\section{Dilution experiments}

Total, HDNA, and LDNA bacterial gross growth rates ranged from 0.41 to $1.72,0.44$ to 1.92 , and 0.25 to $0.73 \mathrm{~d}^{-1}$, respectively (Fig. 3). HDNA bacterial gross growth rates were significantly higher than LDNA bacterial gross growth rates $(p<0.001)$. Seasonally, HDNA and LDNA bacterial gross growth rates were highest during summer 2004, followed by winter 2005, and lowest during fall 2006 (p < 
Table 2. Phytoplankton biomass (chl a), total bacterial abundance (TBAC), percent high DNA content bacteria (\%HDNA), and ciliate, dinoflagellate (Dino), and heterotrophic nanoflagellate (HNF) biomass at Florida Bay sampling sta-

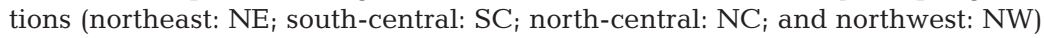
across 3 seasons. nd: not determined

\begin{tabular}{|c|c|c|c|c|c|c|}
\hline $\begin{array}{l}\text { Season } \\
\text { Stn }\end{array}$ & $\begin{array}{l}\text { Chl a } \\
\left(\mu \mathrm{g} \mathrm{l}^{-1}\right)\end{array}$ & $\begin{array}{c}\text { TBAC } \\
\left(\times 10^{9} \text { cells } l^{-1}\right)\end{array}$ & $\%$ HDNA & $\begin{array}{l}\text { Ciliates } \\
\left(\mu \mathrm{C} \mathrm{C}^{-1}\right)\end{array}$ & $\begin{array}{c}\text { Dino } \\
\left(\mu \mathrm{C} \mathrm{C}^{-1}\right)\end{array}$ & $\begin{array}{c}\mathrm{HNF} \\
\left(\mu \mathrm{C} \mathrm{C}^{-1}\right)\end{array}$ \\
\hline \multicolumn{7}{|c|}{ Summer 2004} \\
\hline NE & 0.4 & 1.0 & 51.8 & 8.6 & 54.0 & 2.8 \\
\hline $\mathrm{SC}$ & 0.6 & 0.7 & 66.1 & 5.9 & 38.8 & 1.2 \\
\hline $\mathrm{NC}$ & 0.3 & 1.5 & 69.8 & 2.1 & 16.1 & 3.1 \\
\hline NW & 1.2 & 1.1 & 56.5 & 10.4 & 4.4 & 3.4 \\
\hline \multicolumn{7}{|c|}{ Winter 2005} \\
\hline NE & 0.1 & 0.6 & 59.2 & 7.0 & 5.8 & 1.4 \\
\hline $\mathrm{SC}$ & 0.2 & 0.7 & 79.4 & 3.2 & 1.9 & 1.6 \\
\hline $\mathrm{NC}$ & 0.4 & 1.5 & 55.6 & 8.7 & 25.7 & 5.4 \\
\hline NW & 2.0 & 1.1 & 68.8 & 5.7 & 1.6 & 3.0 \\
\hline \multicolumn{7}{|c|}{ Fall 2006} \\
\hline NE & 3.3 & 1.0 & 68.4 & 1.7 & 15.2 & 6.4 \\
\hline $\mathrm{SC}$ & nd & nd & nd & nd & nd & nd \\
\hline $\mathrm{NC}$ & 28.1 & 15.2 & 85.1 & 14.5 & 29.3 & 26.6 \\
\hline NW & 1.8 & 0.9 & 71.5 & 1.5 & 5.9 & 2.2 \\
\hline
\end{tabular}
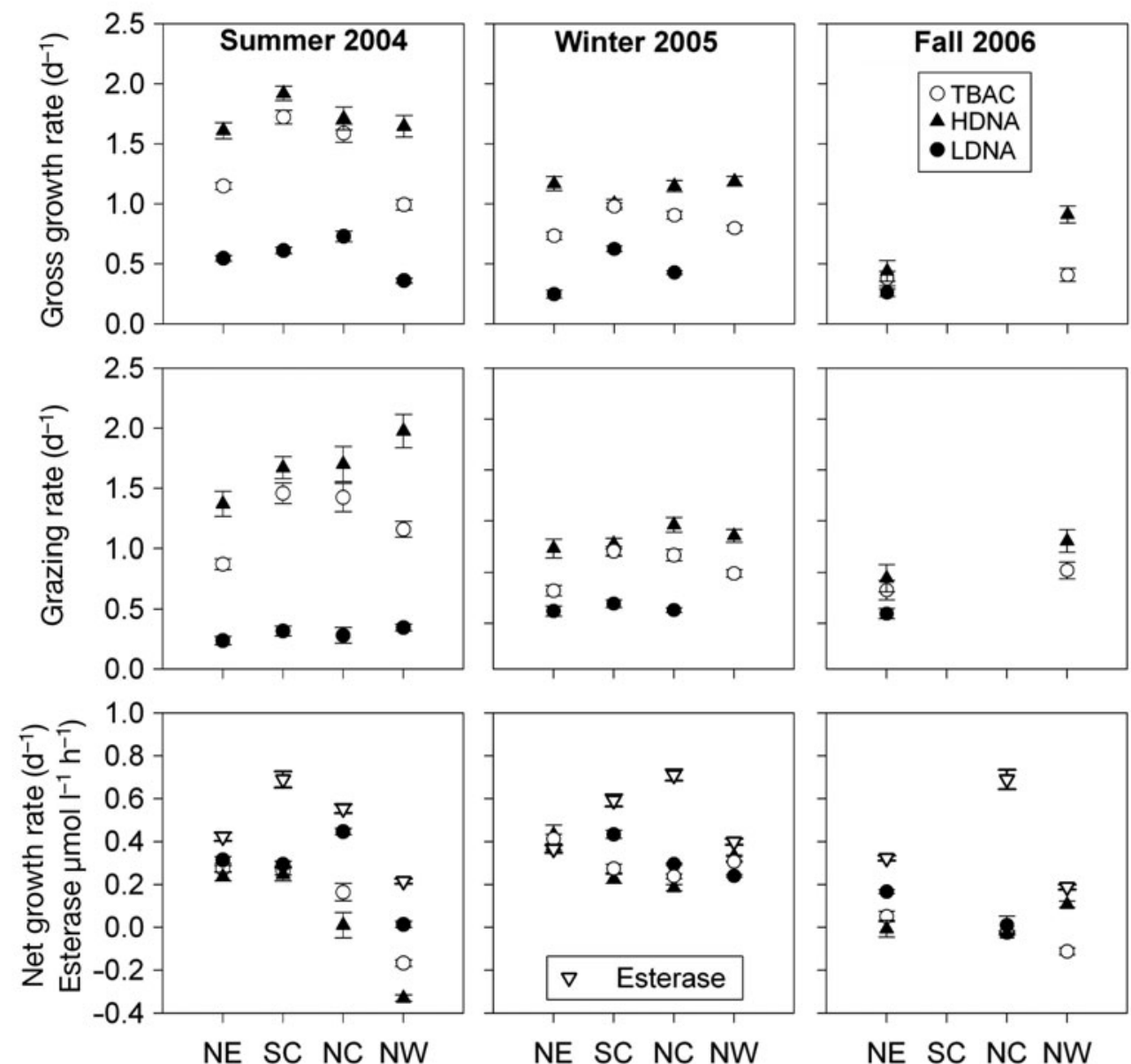

Fig. 3. Growth gross, grazing mortality, and net growth rates with ambient esterase activity indicated for total bacterial abundance (TBAC), high DNA content (HDNA), and low DNA content (LDNA) bacteria at northeast (NE), south-central (SC), northcentral (NC), and northwest (NW) Florida Bay sampling stations. Rates were not determined at SC in fall 2006. Non-significant serial dilution regression values are not presented 
Grazing mortality rates of total, HDNA, and LDNA bacteria ranged from 0.32 to $1.46,0.44$ to 1.98 , and 0.10 to $0.35 \mathrm{~d}^{-1}$, respectively (Fig. 3). HDNA bacterial grazing mortality was significantly higher than LDNA bacterial mortality $(\mathrm{p}<0.001)$, indicating that HDNA bacteria were consistently grazed more heavily than LDNA bacteria. Total, HDNA, and LDNA bacterial net growth rates ranged from -0.17 to $0.41,-0.33$ to 0.43 , and 0.01 to $0.45 \mathrm{~d}^{-1}$, respectively (Fig. 3). HDNA bacterial net growth rates were significantly lower than LDNA bacteria ( $p<0.001$ ). During winter 2005, HDNA

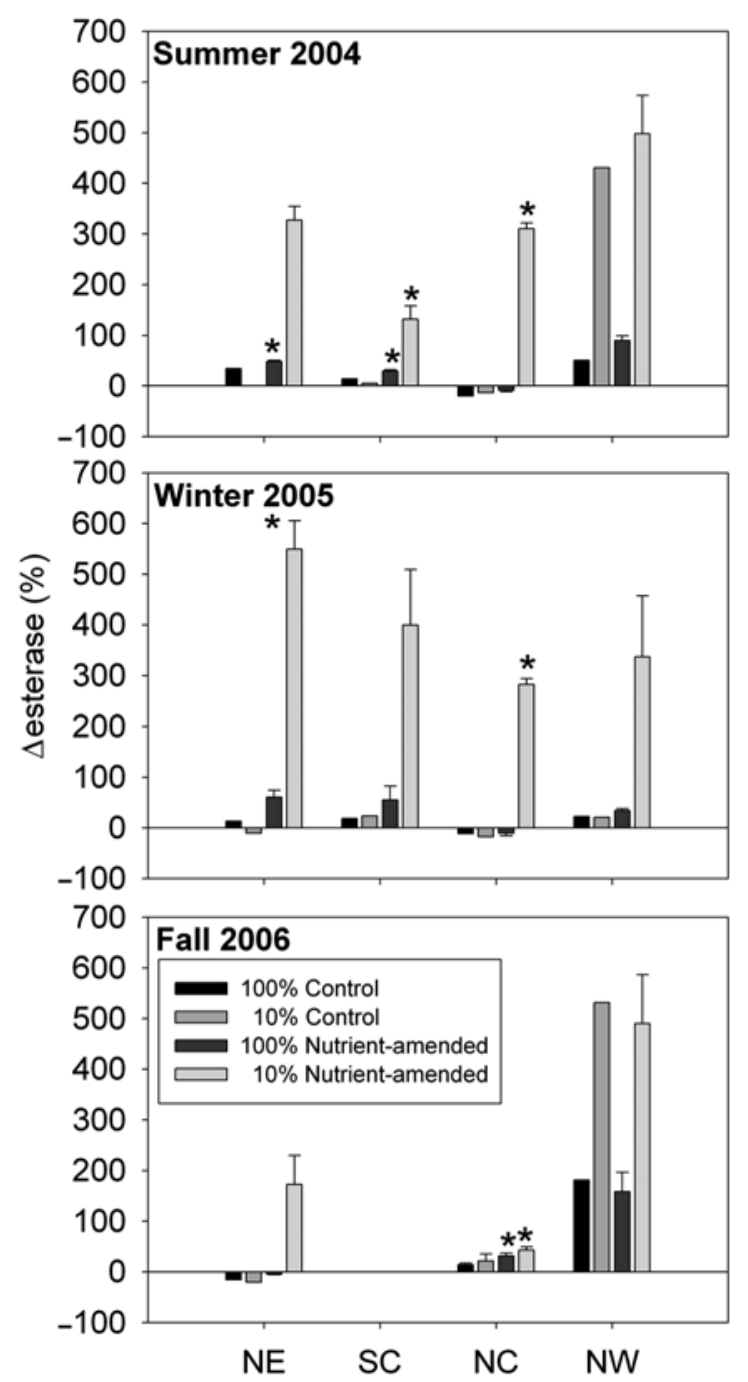

Fig. 4. $\Delta$ esterase (see 'Esterase activity') determined for $100 \%$ (ambient grazing pressure) and 10\% (reduced grazing pressure) of whole-water dilutions and control (no nutrients) and nutrient-amended treatments at northeast (NE), south-central (SC), north-central (NC), and northwest (NW) sampling stations. Error bars (SE) for nutrient-enriched treatments indicate error between $<25 \mu \mathrm{m}+\mathrm{N}+\mathrm{P}, \mathrm{N}+\mathrm{P}$, and $\mathrm{C}+\mathrm{N}+\mathrm{P}$ treatments. ${ }^{*}$ Significant difference $(\mathrm{p} \leq 0.05)$ between control and nutrient-amended esterase activities and LDNA net growth rates were significantly higher than in summer 2004 and fall 2006 ( $p$ < 0.001). Spatially, HDNA and LDNA bacterial net growth rates were lowest at NW and highest at NE and SC ( $p<$ 0.001).

\section{Esterase activity}

Ambient esterase activity ranged from 0.19 to $0.71 \mu \mathrm{mol} \mathrm{l}^{-1} \mathrm{~h}^{-1}$ and was significantly higher at central bay stations $(p=0.014)$, though esterase activity did not increase significantly during the phytoplankton blooms in fall 2006 (Fig. 3). In fall 2006, $69 \pm 8 \%$ of whole water esterase activity was dissolved (i.e. detected in $0.2 \mu \mathrm{m}$ filtrate), while $<4 \%$ of bacterial cells slipped past the $0.2 \mu \mathrm{m}$ filter (C. J. Williams unpubl. data). $T_{0}$ esterase activities were similar in 100 and $10 \%$ dilutions, suggesting that most of esterase activity was freely dissolved in the water column and initially not dependent on microbial biomass.

$\Delta$ esterase, calculated as [(EsteraseActivity $T_{T_{24}}-$ EsteraseActivity $_{T_{0}}$ )/EsteraseActivity ${ }_{T_{0}}$ ] as \%, in $100 \%$ control and nutrient-amended treatments were generally similar. $T_{24}$ esterase activities in $100 \%$ dilutions did not deviate much from $T_{0}$ (ambient) esterase activities (Fig. 4). In general, $\Delta$ esterase was higher in $10 \%$ nutrient-amended treatments than in $10 \%$ control treatments. However, during summer 2004 at NW and during fall 2006, $\Delta$ esterase increased greatly in both $10 \%$ control and nutrient-amended treatments (Fig. 4). Comparing Figs. $3 \& 4$, a surprising pattern emerges: $\Delta$ esterase was similar between control and nutrientamended $10 \%$ treatments when TBAC net growth rates were near 0 or negative. This pattern also corresponds to DIN concentrations having been relatively low when compared to $\mathrm{PO}_{4}{ }^{3-}$ concentrations, i.e. low $\mathrm{N}: \mathrm{P}$ ratios (Table 1). To explore these results in more detail, the influence of nutrients, biomass, and net growth rates on $\Delta$ esterase and ambient esterase activity was explored by correlation and linear regression analyses.

\section{Correlation and regression analyses}

TBAC correlated positively with chl a $(\mathrm{r}=0.75, \mathrm{p}=$ 0.008 ) and $\operatorname{HNF}(\mathrm{r}=0.91, \mathrm{p}<0.001)$. In contrast, total, HDNA, and LDNA bacterial abundance did not relate to TBAC gross growth rate or TBAC grazing mortality rate. Similarly, ciliate, dinoflagellate, and HNF biomass did not relate to total, HDNA, and LDNA bacterial grazing mortality rates. TBAC grazing mortality rates were only positively correlated with TBAC gross growth rates $(\mathrm{r}=0.88, \mathrm{p}<0.001)$. 
TBAC net growth rates, however, were influenced by environmental conditions and esterase activity. Individual linear relationships were observed for TBAC net growth rates and ln-transformed DIN, $\mathrm{PO}_{4}{ }^{3-}$, $\mathrm{N}: \mathrm{P}$ ratio, and ambient esterase activity, where $\mathrm{NH}_{4}{ }^{+}$ and $\mathrm{NO}_{2}{ }^{-}+\mathrm{NO}_{3}{ }^{-}$explained the most and least, respectively, variability in TBAC net growth rate (Table 3). Stepwise multiple regression with covariates removed indicated that $\mathrm{NH}_{4}{ }^{+}$concentration and ambient esterase activities were significant influences on TBAC net growth rate (for ln-transformed data, $\mathrm{R}^{2}=0.75$ ). When the covariate, ln-transformed N:P ratio was substituted for $\mathrm{NH}_{4}{ }^{+}$concentration, the $\mathrm{R}^{2}$ of TBAC net growth rate multiple regression was reduced slightly to 0.69 . Both multiple regressions indicate that bacterial net growth rate was higher when $\mathrm{NH}_{4}{ }^{+}$concentration and esterase activity were higher (Table 3).

Why esterase activity relates to TBAC net growth rate is not obvious. Instead, the difference between $10 \% \Delta$ esterase nutrient-amended and $10 \% \Delta$ esterase control treatments hereafter the difference in $10 \%$ $\Delta$ esterase) was the key to the relationship between esterase activity and bacterial net growth rate (Tables $1 \& 3$, Figs. $3 \& 4$ ). The difference in 10\% $\Delta$ esterase related to ln-transformed DIN, $\mathrm{PO}_{4}{ }^{3-}, \mathrm{N}: \mathrm{P}$ ratio, and TBAC net growth rate, where $\mathrm{N}$ :P ratio and $\mathrm{NO}_{2}{ }^{-}+\mathrm{NO}_{3}{ }^{-}$explained the most and least, respectively, variability in the difference in $10 \% \Delta$ esterase. Stepwise multiple regression with covariates removed indicated that ln-transformed $\mathrm{PO}_{4}{ }^{3-}$ and $\mathrm{NH}_{4}{ }^{+}$concentrations explained most of the variability in the differ- ence in $10 \% \Delta$ esterase $\left(\mathrm{R}^{2}=0.72\right)$, whereby $\mathrm{NH}_{4}{ }^{+}$concentration could be replaced with TBAC net growth rate without a loss in the relationship of the model $\left(\mathrm{R}^{2}=\right.$ 0.69 , Table 3). The difference in $10 \% \Delta$ esterase was minimal (i.e. near 0) when $\mathrm{PO}_{4}{ }^{3-}$ concentration was high and $\mathrm{NH}_{4}{ }^{+}$concentration or TBAC net growth rate was low. These relationships indicated that under ambient nutrient concentrations, esterase activity significantly increased with the experimental reduction in grazing pressure, but only when bacterial net growth rates indicated that grazing mortality rates met or exceeded bacterial gross growth rates (Table 3, Figs. 3 \& 4).

\section{DISCUSSION}

\section{Bacterial growth and grazing mortality}

Two clusters of bacteria (i.e. HDNA and LDNA bacteria) are differentiated commonly by flow cytometry based on variations in the relative size and nucleic acid content of stained bacteria cells (Marie et al. 1997, Gasol et al. 1999, Jochem et al. 2004). HDNA bacteria have higher relative DNA fluorescence and on average higher side-angle light scatter than LDNA bacteria. LDNA bacteria are the dominant fraction of the bacterial community in low-nutrient marine environments, but HDNA bacteria production and growth rates on average tend to surpass the numerically dominant LDNA bacteria (our Fig. 3; Gasol et al. 1999, Jochem et

Table 3. Linear and stepwise multiple regression analysis using total bacterial (TBAC) net growth rate and the difference between $10 \%$ nutrient-amended $\Delta$ esterase and $10 \%$ control $\Delta$ esterase as dependent variables. The difference in $10 \% \Delta$ esterase represents bottom-up and top-down control of bacterial esterase activity in dilution experiments, where values near 0 indicate primarily top-down influence on esterase activity and larger differences, values $>0$, indicate both bottom-up and top-down influence on esterase activity. Mean and SE of independent variables $\left(b_{1}, b_{2}\right)$ and model constant coefficients, regression coefficient, and $F$-test statistics are given for each relationship

\begin{tabular}{|c|c|c|c|c|c|c|c|c|c|}
\hline Dependent variable $(y)$ & $x_{1}$ & $b_{1} \pm \mathrm{SE}$ & $x_{2}$ & $b_{2} \pm \mathrm{SE}$ & Const. \pm SE & $\mathrm{R}^{2}$ & $\mathrm{df}$ & $F$ & $\mathrm{p}$ \\
\hline \multicolumn{10}{|c|}{ Linear 2-variable regression } \\
\hline \multirow{5}{*}{$\begin{array}{l}\text { TBAC net growth } \\
\text { rate }\left(\mathrm{d}^{-1}\right)\end{array}$} & $\ln \left(\mathrm{NH}_{4}^{+}\right)$ & $0.13 \pm 0.02$ & & & $0.26 \pm 0.03$ & 0.65 & 1,28 & 52.9 & 0.001 \\
\hline & $\ln \left(\mathrm{NO}_{2}^{-}+\mathrm{NO}_{3}^{-}\right)$ & $0.21 \pm 0.09$ & & & $0.09 \pm 0.04$ & 0.16 & 1,28 & 5.3 & 0.03 \\
\hline & $\ln \left(\mathrm{PO}_{4}^{3-}\right)$ & $-0.17 \pm 0.06$ & & & $-0.36 \pm 0.18$ & 0.23 & 1,28 & 8.2 & 0.008 \\
\hline & $\ln (\mathrm{N}: \mathrm{P})$ & $0.14 \pm 0.03$ & & & $-0.35 \pm 0.10$ & 0.47 & 1,28 & 24.7 & 0.001 \\
\hline & $\ln ($ Esterase $)$ & $0.22 \pm 0.06$ & & & $0.34 \pm 0.06$ & 0.28 & 1,31 & 12.3 & 0.001 \\
\hline \multirow{5}{*}{$\begin{array}{l}\text { Difference in } 10 \% \\
\Delta \text { esterase }\left(\mu \mathrm{mol} \mathrm{l}^{-1} \mathrm{~h}^{-1}\right)\end{array}$} & $\ln \left(\mathrm{NH}_{4}^{+}\right)$ & $0.60 \pm 0.09$ & & & $1.58 \pm 0.13$ & 0.63 & 1,30 & 50.1 & 0.001 \\
\hline & $\ln \left(\mathrm{NO}_{2}^{-}+\mathrm{NO}_{3}^{-}\right)$ & $1.50 \pm 0.37$ & & & $0.67 \pm 0.15$ & 0.36 & 1,30 & 16.5 & 0.001 \\
\hline & $\ln \left(\mathrm{PO}_{4}^{3-}\right)$ & $-1.15 \pm 0.23$ & & & $-2.25 \pm 0.67$ & 0.45 & 1,30 & 24.8 & 0.001 \\
\hline & $\ln (\mathrm{N}: \mathrm{P})$ & $0.75 \pm 0.10$ & & & $-1.51 \pm 0.34$ & 0.66 & 1,30 & 57.6 & 0.001 \\
\hline & TBAC net & $3.80 \pm 0.59$ & & & $0.50 \pm 0.14$ & 0.61 & 1,27 & 42.2 & 0.001 \\
\hline \multicolumn{10}{|c|}{ Linear stepwise multiple regression } \\
\hline \multirow{2}{*}{$\begin{array}{l}\text { TBAC net growth } \\
\text { rate }\left(\mathrm{d}^{-1}\right)\end{array}$} & $\ln \left(\mathrm{NH}_{4}^{+}\right)$ & $0.11 \pm 0.02$ & $\ln ($ Esterase $)$ & $0.13 \pm 0.04$ & $0.35 \pm 0.04$ & 0.75 & 2,27 & 41.0 & 0.001 \\
\hline & $\ln (\mathrm{N}: \mathrm{P})$ & $0.13 \pm 0.02$ & $\ln ($ Esterase $)$ & $0.19 \pm 0.04$ & $-0.15 \pm 0.09$ & 0.69 & 2,27 & 30.3 & 0.001 \\
\hline \multirow{2}{*}{$\begin{array}{l}\text { Difference in } 10 \% \\
\Delta \text { esterase }\left(\mu \mathrm{mol} \mathrm{l}^{-1} \mathrm{~h}^{-1}\right)\end{array}$} & $\ln \left(\mathrm{PO}_{4}{ }^{3-}\right)$ & $-0.61 \pm 0.20$ & $\ln \left(\mathrm{NH}_{4}^{+}\right)$ & $0.46 \pm 0.09$ & $-0.27 \pm 0.61$ & 0.72 & 2,29 & 37.5 & 0.001 \\
\hline & $\ln \left(\mathrm{PO}_{4}{ }^{3-}\right)$ & $-0.58 \pm 0.22$ & TBAC net & $3.03 \pm 0.61$ & $-1.05 \pm 0.60$ & 0.69 & 2,26 & 29.2 & 0.001 \\
\hline
\end{tabular}


al. 2004). The \%HDNA bacteria fraction increases in coastal areas and with increasing resource availability (Jochem et al. 2004, Longnecker et al. 2006). The HDNA bacteria fraction of the Laguna Madre and Florida Bay seagrass estuaries made up $\sim 70 \%$ of the TBAC, which was comparable to the Pacific Oregon shelf upwelling system (our Fig. 3; Jochem et al. 2004, Longnecker et al. 2006). The high fraction of HDNA bacteria in low nutrient seagrass estuaries is likely influenced by high rates of benthic macrophyte productivity stimulating heterotrophic bacterioplankton activity (Ziegler \& Benner 1999, Jochem et al. 2004).

HDNA bacteria are more metabolically active and have higher rates of protein synthesis than LDNA bacteria (Longnecker et al. 2006) and are positively related to live-stained, active bacterial cells (Gasol et al. 1999). These attributes suggested that the HDNA bacteria are the active fraction of the bacterial community (Gasol et al. 1999). Unlike HDNA bacteria, the identity and activity of LDNA bacteria is not agreed upon. LDNA bacteria were first labeled as inactive (Gasol et al. 1999), but this group can incorporate ${ }^{3} \mathrm{H}$ thymidine and ${ }^{3} \mathrm{H}$-leucine (Longnecker et al. 2006) and can have positive gross growth rates (our Fig. 3; Jochem et al. 2004). In Florida Bay, gross growth rates of LDNA bacteria were consistently positive. LDNA net growth rates were near 0 or positive and overall significantly higher than HDNA net growth rates (Fig. 3). HDNA communities were at times growing, stable, or in a state of decline, but consistently grazed more heavily than LDNA bacteria. These results indicate that LDNA bacteria in Florida Bay were active (i.e. growing), but were grazed less heavily than HDNA bacteria. High grazing rates on HDNA bacteria might have been a result of protist grazing preference for actively growing, metabolically more active, and/or slightly larger (as reflected by higher light scatter) bacteria (Gasol et al. 1999, Jürgens \& Matz 2002).

These dilution experiment results were, however, inconsistent with the observed spatiotemporal patterns in bacterial abundance and protist biomass. TBAC versus HNF biomass and TBAC gross growth versus TBAC grazing mortality rates correlated positively, but gross growth and grazing mortality rates were unrelated to bacterial abundance and protist biomass. In addition, dilution experiments indicated that LDNA bacteria populations were increasing faster than HDNA populations. From 2004 through 2006, the LDNA community did not, however, overtake the HDNA community in numerical abundance (our Table 2; C. J. Williams unpubl. data). These inconsistencies suggest that the heterotrophic bacterioplankton community in Florida Bay is influenced by other loss factors, which were absent from the dilution experiments.
Florida Bay is a shallow, well-mixed estuary with easily resuspendable sediment. During wind events, which occur commonly, benthic nutrient resources and microorganisms are mixed into the water column (Lawrence et al. 2004). The bottle experiments separate the pelagic community from the benthic community, which may alter the pelagic microbial food web by preventing natural benthic-pelagic interaction. In addition, it is reasonable to suspect that heterotrophic bacterioplankton sustain grazing losses from benthic (sponges and mussels) and epiphytic (attached to seagrass and red mangrove drop roots) suspensionfeeding organisms. For example, sponge filtration/ grazing experiments in Florida Bay found that sponges were capable of removing half of water column phytoplankton biomass within 30 to 60 min (Peterson et al. 2006). Given that Synechococcus spp. are the most abundant phytoplankton in Florida Bay and that sponges can exert significant grazing control on this plankton size-class (Peterson et al. 2006), we hypothesize that sponges might contribute also to heterotrophic bacterioplankton mortality.

Even in the absence of this potentially significant benthic mortality component to heterotrophic bacterioplankton, TBAC grazing mortality rates at times exceeded TBAC gross growth rates, suggesting topdown control of bacterioplankton growth by bacterivorous protists (Fig. 3). Grazing rates suppressed TBAC growth more frequently at the western bay station. However, spatial patterns in trophic influences on bacterial growth did not conform to the expected longterm east to west nutrient gradient in Florida Bay (Boyer et al. 1999), where the HNF:bacteria ratio increased in the central and western bay (Lavrentyev et al. 1998). Instead, TBAC net growth rates were indicative of top-down trophic control (i.e. TBAC grazing mortality $\geq$ gross growth) when $\mathrm{N}: \mathrm{P}$ ratios, $\mathrm{NH}_{4}{ }^{+}$ concentration, and ambient esterase activity were low but $\mathrm{PO}_{4}{ }^{3-}$ concentration was relatively high (Table 3). With increasing phosphorus-limited N:P stoichiometry and $\mathrm{NH}_{4}{ }^{+}$concentration, protistan grazing accounted for a diminishing amount of TBAC daily gross growth (i.e. increasingly positive TBAC net growth rates), indicating bottom-up control of heterotrophic bacteria community growth. These results suggest that an apparent shift from bottom-up to top-down trophic control of heterotrophic bacterial growth occurred when N:P ratios were near Redfield stoichiometry or indicative of nitrogen-limitation and $\mathrm{NH}_{4}{ }^{+}$was depleted (Tables 1 \& 3, Fig. 3).

This N:P stoichiometry-dependent shift in the trophic influence on heterotrophic bacteria communities in Florida Bay may stem from a combination of resource competition between bacterio- and phytoplankton and altered protistan grazing activity in 
response to environmental cues. In Florida Bay, phytoplankton can outcompete heterotrophic bacteria for $\mathrm{PO}_{4}{ }^{3-}$ when chl a concentration is above 1 to $2 \mu \mathrm{g} \mathrm{l} \mathrm{l}^{-1}$ (Cotner et al. 2000). In addition, long-term trends in phytoplankton biomass indicate that chl a increased with increasing total phosphorus (TP) concentration and decreasing $\mathrm{NH}_{4}{ }^{+}$concentration (Boyer et al. 1997, J. N. Boyer unpubl. data, http://serc.fiu.edu/wqmnetwork). In the present study, chl a correlated negatively with DIN concentration, suggesting that phytoplankton contributed to the draw-down of water column inorganic nitrogen resources and shift in N:P stoichiometry. In addition, during the fall 2006 phytoplankton blooms, water column $\mathrm{NH}_{4}{ }^{+}$regeneration was less than heterotrophic $\mathrm{NH}_{4}{ }^{+}$uptake, and light $\mathrm{NH}_{4}{ }^{+}$uptake was significantly higher than dark $\mathrm{NH}_{4}{ }^{+}$ uptake, indicating significant autotrophic consumption of $\mathrm{NH}_{4}^{+}$(M. J. McCarthy \& W. S. Gardner unpubl. data). Hence, greater resource competition with phytoplankton seemed to render heterotrophic bacteria more susceptible to top-down regulation of community growth. Assuming that water column N:P ratios are indicative of cellular resource ratios of bacterio- and phytoplankton, the activity of bacterivorous protists may have increased in response to a shift toward more favorable prey nutrient status. For example, Ochromonas danica, a mixotrophic nanoflagellate, ingested cultured bacteria with low C:N:P ratios faster than cells with high C:N:P ratios (Shannon et al. 2007). Thus, environmental conditions can influence the availability of prey bacteria that are preferentially grazed by bacterivores, which with resource competition between bacteria and phytoplankton could influence further trophic dynamics within the aquatic ecosystem. In the present study, it appears that when ambient $\mathrm{NH}_{4}{ }^{+}$was depleted and N:P reached stoichiometrically balanced and/or nitrogen-limited conditions, bacterivory became a major controlling factor for bacterial community growth.

\section{Significance of esterase}

In natural systems, esterase/lipase activities vary widely in their overall importance, suspected enzyme source, and interpretation. In general, esterase/lipase activity decreases with increasing fatty acid chain length of the target substrate (Prim et al. 2003). Esterase activities in Florida Bay (C7 substrate used; Williams \& Jochem 2006, the present study) exceeded esterase/lipase activities in the Caribbean Sea (lipase substrate not specified; Rath et al. 1993), Hudson River Estuary (C16; Taylor et al. 2003), hypereutrophic Danube River (C16; Gajewski et al. 1997), and the coastal Pacific Ocean (Scripps Pier, C18:1; Martinez et al. 1996) but were lower than in Lake Gardno (eutrophic estuarine lake, northern Poland, C2 and C4; Mudryk \& Skórczewski 2004). These systems vary widely from oligotrophic to highly eutrophic, but ambient enzyme activities conformed to expectations based on model substrate carbon length. This difference in reactivity of esterase/lipase model substrates makes comparison between studies difficult. Enzyme activities and their corresponding interpretations are products of the carbon length of the model substrate used in the extracellular enzyme assay and the bacterial community's environment, metabolic activity, and growth rate (Fiksdal et al. 1989, Jaeger et al. 1994, Gajewski et al. 1997, Klatt \& LaPara 2003, Chen \& LaPara 2006).

In Florida Bay, ambient esterase activity measured using MUF-heptanoate was related significantly to TBAC net growth rates (Table 3 ). $\Delta$ esterase from dilution experiments indicated that when the bacterial community was not growing because grazing mortality rates exceeded gross growth rates, the bacterial community required the reduction of grazing pressure, not nutrient addition, to increase esterase activity (Table 3, Figs. $3 \& 4$ ). When the bacterial community had positive net growth rates, nutrient addition in addition to reduction of grazing pressure was required to stimulate esterase activity. These results suggest that esterase activity was linked to bacterial community growth in Florida Bay and that ambient esterase activity was restrained by grazing activities.

Interactions between esterase activity, phosphorus concentration, and TBAC net growth rates (Table 3) should result in a general relationship between in situ TBAC, phosphorus concentration, esterase activity, and BP. To look for this relationship, data collected at 7 Florida Bay stations from May 2004 through November 2006 ( $\mathrm{n}=196$; Williams \& Jochem 2006, authors' unpubl. data) were subjected to stepwise multiple regression analysis, where ln-transformed TBAC was the dependent variable and ln-transformed TP, BP $\left({ }^{3} \mathrm{H}\right.$ leucine incorporation), and esterase activity were the independent variables. Ln-transformed TBAC related significantly and positively with $\mathrm{TP}, \mathrm{BP}$, and esterase activity $\left(\mathrm{R}^{2}=0.39, F_{3,193}=40.8, \mathrm{p}<0.001\right)$. This relationship accounted for $\sim 40 \%$ of the variability in bacterial abundance and was based on parameters that should indicate bacteria growth in Florida Bay. This relationship did not include bacterial loss terms such as sedimentation, viral lysis, and grazing mortality or resource competition with phytoplankton and benthic macrophytes, which likely play an equally, if not more important, role in influencing TBAC in seagrass estuaries. Still, the relationship does support the observations that esterase activity is related positively to bacterial community growth (Table 3 ). 
In the Caribbean Sea, cell-specific lipase activity correlated positively with bacterial biomass and turnover times, indicating that lipase activity increased when bacterial biomass was higher and the bacterial community turned over more rapidly (Rath et al. 1993). Similar links of esterase/lipase activities have been observed in culture experiments, in which enzyme activity related to exponential bacterial growth (Jaeger et al. 1994, Gobbetti et al. 1997). Using MUF-palmitate, Gajewski et al. (1997) suggested that lipase activity in the Danube River was a result of bacterial metabolic activity and growth rates, whereby lipase production in natural bacterial communities might be limited by nutrient concentrations, grazing, and viral lysis.

Given these strong esterase activity responses to changes in nutrient availability and grazing pressure, it is likely that extracellular esterases supply simple carbon substrates (free organic acids) for bacterial catabolism. We hypothesize that positive relationships between bacterial community growth and esterase activity were driven by increases in bacterial carbon demand, which occurred when bacteria were relieved from bottom-up and top-down growth restraints. This hypothesis is conditional and assumes that heterotrophic bacterial growth is not limited by carbon, specifically lipid substrates. In the absence of suitable lipid substrates, stimulation of esterase activity in response to changes in bacterial growth rates is unlikely (Chen \& LaPara 2006). Under this hypothesis and assumption, extracellular esterase activity seems implicitly tied to trophic influences on bacterial growth and metabolic activity (Table 3, Gajewski et al. 1997), which regulate, in part, the carbon demand of heterotrophic bacteria.

\section{CONCLUSION}

In Florida Bay, heterotrophic bacterioplankton growth and esterase activity were influenced by bottom-up and top-down processes. Regardless of resource levels, HDNA bacteria were grazed more heavily than the metabolically active LDNA population. The ability of bacterivorous protists to restrict bacterioplankton community growth and carbon use was dependent on ambient nutrient concentrations and the relative ratio between DIN and phosphate. Protistan grazing rates exceed bacterial gross growth rates and suppressed esterase activity when ambient N:P stoichiometry indicated balanced and/or nitrogen-limited growth. When N:P ratios indicated phosphorus-limited conditions due to increased $\mathrm{NH}_{4}{ }^{+}$concentration, bacterioplankton growth was higher than bacterial mortality and bacterial net community growth was controlled by bottom-up processes. Under high ambient N:P ratios, both nutrient addition and grazer reduction were needed, however, to stimulate esterase activity beyond ambient activities. The dilution experiments suggested complex interactions between resources, phytoplankton, bacteria, and protistan grazers, whereby competition between phytoplankton and bacteria for inorganic resources and more nutritionally balanced growth conditions allowed protistan grazing to exceed bacterial growth. Thus, depending on ambient nutrient concentrations and stoichiometry, heterotrophic bacteria growth and carbon use shifted between bottom-up and top-down control.

Acknowledgements. We thank W. Gardner and M. McCarthy for providing nutrient and hydrological data and the Keys Marine Laboratory for providing boat transportation and laboratory facilities. This research was funded by NOAA COP grants NA04NOS4780020 and NA04NOS4780018.

\section{LITERATURE CITED}

Agustí S, Satta MP, Mura MP, Benavent E (1998) Dissolved esterase activity as a tracer of phytoplankton lysis: evidence of high phytoplankton lysis rates in the northwestern Mediterranean. Limnol Oceanogr 43:1836-1849

Bornscheuer UT (2002) Microbial carboxyl esterases: classification, properties and applications in biocatalysis. FEMS Microbiol Rev 26:73-81

Boyer JN, Fourqurean JW, Jones RD (1997) Spatial characterization of water quality in Florida Bay and Whitewater Bay by multivariate analyses: zones of similar influence. Estuaries 20:743-758

Boyer JN, Fourqurean JW, Jones RD (1999) Seasonal and long-term trends in the water quality of Florida Bay (1989-1997). Estuaries 22:417-430

> Calbet A, Landry MR, Nunnery S (2001) Bacteria-flagellate interactions in the microbial food web of the oligotrophic subtropical North Pacific. Aquat Microb Ecol 23:283-292

Caron DA (2001) Protistan herbivory and bacteriovory. In: Paul J (ed) Marine microbiology: methods in microbiology, Vol 30. Academic Press, London, p 289-316

Chen R, LaPara TM (2006) Aerobic biological treatment of low-strength synthetic wastewater in membrane-coupled bioreactors: the structure and function of bacterial enriched cultures as the net growth rate approaches zero. Microb Ecol 51:99-108

> Cotner JB, Sada RH, Bootsma H, Johehgen T, Cavaletto JF, Gardner WS (2000) Nutrient limitation of heterotrophic bacteria in Florida Bay. Estuaries 23:611-620

> Fiksdal L, Pommepuy M, Derrien A, Cormier M (1989) Production of 4-methylumbelliferyl heptanoate hydrolase by Escherichia coli exposed to seawater. Appl Environ Microbiol 55:2424-2427

First MR, Lavrentyev PJ, Jochem FJ (2007) Patterns of microzooplankton growth in dilution experiments across a trophic gradient: implications for herbivory studies. Mar Biol 151:1929-1940

> Fourqurean JW, Jones RD, Zieman JC (1993) Processes influencing water column nutrient characteristics and phosphorus limitation of phytoplankton biomass in Florida Bay, FL, USA: influences from spatial distributions. Estuar Coast Shelf Sci 36:295-314 
Gajewski AJ, Kirschner AKT, Velimirov B (1997) Bacterial lipolytic activity in a hypertrophic dead arm of the river Danube in Vienna. Hydrobiologia 344:1-10

- Gardner WS, Bootsma HA, Evans C, St. John PA (1995) Improved chromatographic analysis of ${ }^{15} \mathrm{~N}:{ }^{14} \mathrm{~N}$ ratios in ammonium or nitrate for isotope dilution experiments. Mar Chem 48:271-282

Gasol JM, Zweifel UL, Peters F, Fuhrman JA, Hagström ^̊ (1999) Significance of size and nucleic acid content heterogeneity as measured by flow cytometry in natural planktonic bacteria. Appl Environ Microbiol 65:4475-4483

> Gasol JM, Pedros-Alio C, Vaque C (2002) Regulation of bacterial assemblages in oligotrophic plankton systems: results from experimental and empirical approaches. Ant Leeuwenhoek 81:435-452

Gilham D, Lehner R (2005) Techniques to measure lipase and esterase activity in vitro. Methods 36:139-147

Gobbetti M, Smacchi E, Corsetti A (1997) Purification and characterization of a cell surface-associated esterase from Lactobacillus fermentum DT41. Int Dairy J 7:13-21

Jaeger KE, Ransac S, Dijkstra BW, Colson C, van Heuvel M, Misset O (1994) Bacterial lipases. FEMS Microbiol Rev 15: 29-63

> Jochem FJ (2001) Morphology and DNA content of bacterioplankton in the northern Gulf of Mexico: analysis by epifluorescence microscopy and flow cytometry. Aquat Microb Ecol 25:179-194

Jochem FJ, Lavrentyev PJ, First MR (2004) Growth and grazing rates of bacteria groups with different apparent DNA content in the Gulf of Mexico. Mar Biol 145:1213-1225

Jürgens K, Matz C (2002) Predation as a shaping force for the phenotypic and genotypic composition of planktonic bacteria. Ant Leeuwenhoek 81:413-434

Klatt CG, LaPara TM (2003) Aerobic biological treatment of synthetic municipal wastewater in membrane-coupled bioreactors. Biotechnol Bioeng 82:313-320

Konopka A, Zakharova T (2002) Evaluation of methods to solubilize and analyze cell-associated ectoenzymes. J Microbiol Methods 51:273-282

Landry MR, Hassett RP (1982) Estimating the grazing impact of marine micro-zooplankton. Mar Biol 67:283-288

Landry MR, Kirshtein J, Constantinou J (1995) A refined dilution technique for measuring the community grazing impact of microzooplankton, with experimental tests in the central equatorial Pacific. Mar Ecol Prog Ser 120: $53-63$

Lavrentyev PJ, Bootsma HA, Johengen TH, Cavaletto JF, Gardner WS (1998) Microbial plankton response to resource limitation: insight from the community structure and seston stoichiometry in Florida Bay, USA. Mar Ecol Prog Ser 165:45-57

Lawrence D, Dagg MJ, Liu H, Cummings SR, Otner PB, Kelble C (2004) Wind events and benthic-pelagic coupling in

Initial editorial responsibility: Howard Browman, Storebø, Norway; Final editorial responsibility: Hans Heinrich Janssen, Oldendorf/Luhe, Germany a shallow subtropical bay in Florida. Mar Ecol Prog Ser 266:1-13

Longnecker K, Sherr BF, Sherr EB (2006) Variation in cellspecific rates of leucine and thymidine incorporation by marine bacteria with high and with low nucleic acid content off the Oregon coast. Aquat Microb Ecol 43:113-125

> Marie D, Partensky F, Jacquet S, Vaulot D (1997) Enumeration and cell cycle analysis of natural populations of marine picoplankton by flow cytometry using the nucleic acid stain SYBR Green I. Appl Environ Microbiol 63: 186-193

- Martinez J, Smith DC, Steward GF, Azam F (1996) Variability in ectohydrolytic enzyme activities of pelagic marine bacteria and its significance for substrate processing in the sea. Aquat Microb Ecol 10:223-230

Menden-Deuer S, Lessard EJ (2000) Carbon to volume relationships for dinoflagellates, diatoms, and other protists plankton. Limnol Oceanogr 45:569-579

Mudryk ZJ, Skórczewski P (2004) Extracellular enzyme activity at the air-water interface of an estuarine lake. Estuar Coast Shelf Sci 59:59-67

Peterson BJ, Chester CM, Jochem FJ, Fourqurean JW (2006) Potential role of sponge community in controlling blooms in Florida Bay. Mar Ecol Prog Ser 328:93-103

Prim N, Sánchez M, Ruiz C, Pastor FIJ, Diaz P (2003) Use of methylumbeliferyl-derivative substrates for lipase activity characterization. J Mol Catal B Enzym 22:339-346

Putt M, Stoecker DK (1989) An experimentally determined carbon-volume ratio for marine oligotrophic ciliates from estuaries and coastal waters. Limnol Oceanogr 34: 1097-1103

> Rath J, Schiller C, Herndl GJ (1993) Ectoenzymatic activity and bacterial dynamics along a trophic gradient in the Caribbean Sea. Mar Ecol Prog Ser 102:89-96

Sanders RW, Caron DA, Berninger UG (1992) Relationship between bacteria and heterotrophic nanoplankton in marine and fresh waters: an inter-ecosystem comparison. Mar Ecol Prog Ser 86:1-14

> Shannon SP, Chrzanowski TH, Grover JP (2007) Prey food quality affects flagellate ingestion rates. Microb Ecol 53: 66-73

Sherr EB, Sherr BF (2002) Significance of predation by protists in aquatic microbial food webs. Ant Leeuwenhoek 81: 293-308

> Taylor GT, Way J, Yu Y, Scranton MI (2003) Ectohydrolase activity in surface waters of the Hudson River and western Long Island Sound estuaries. Mar Ecol Prog Ser 263:1-15

> Williams CJ, Jochem FJ (2006) Ectoenzyme kinetics in Florida Bay: implications for bacterial carbon source and nutrient status. Hydrobiologia 569:113-127

Ziegler S, Benner R (1999) Dissolved organic carbon cycling in a subtropical seagrass dominated lagoon. Mar Ecol Prog Ser 180:149-160

Submitted: October 5, 2007; Accepted: August 13, 2008 Proofs received from author(s): November 14, 2008 